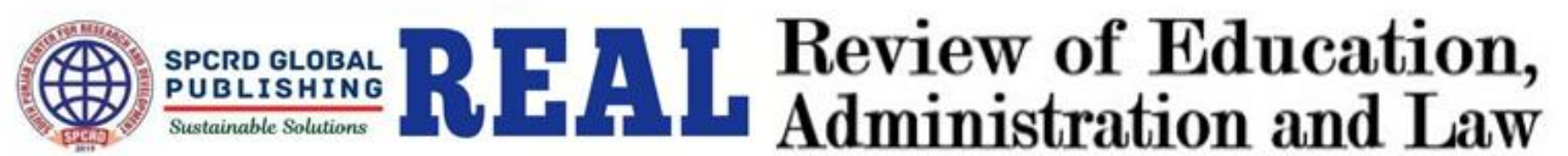 \\ Journal homepage: http://real.spcrd.org ISSN (Print): 2708-1788 ISSN(Online): 2708-3667
}

\section{Pakistan Factor in India's Policy Towards Afghanistan Under BJP Government}

\author{
${ }^{a}$ Shazia Sultan, ${ }^{\mathrm{b}}$ Zahid Anwar, ${ }^{\mathrm{c}}$ Tahira Jabeen \\ ${ }^{a}$ Assistant Professor in political Science, HED KPK, Pakistan \\ ${ }^{\mathrm{b}}$ Department of Political Science, University of Peshawar, KPK Pakistan \\ ${ }^{c}$ LLM Scholar, Faculty of Shari'ah \& Law, International Islamic University Islamabad, Pakistan
}

\begin{tabular}{ll}
\hline ARTICLE DETAILS & ABSTRACT \\
\hline History: & The study offered a brief history of the Pak -Indo relations with \\
Accepted 14 Sep 2020 & Afghanistan and has analyzed some troubles relation among the three \\
Available Online 30 Sep 2020 & states. The Pakistan factor in the Indian-Afghan relations since \\
& independence in general and under BJP government in particular is the \\
part of this investigation. The paper has discussed the importance of & Afghanistan for India and Pakistan and the struggle of both countries for \\
Keywords: & acquiring influence there. The Indian policy of soft power to encircle \\
Indian Policy, Pakistan Factor, & Pakistan has been focused. The paper has tried to explore the current BJP \\
Afghan Government, BJP & government policies regarding peace dialogue among Pakistan US, \\
Government & Taliban and Afghan government and their policy of Intra-Afghan \\
& dialogue. The response of afghan government and people towards Indian \\
JEL Classification: & policies has been highlighted. The paper concludes that nothing is \\
G18, G19 & certain in the mutual relations of these countries as the national interest \\
& of the states does not remain same and permanent all the time and it \\
& usually depend on current regional and international environment. The \\
current close affiliation between Indo-Afghan may take turn to Pak- & Afghan love relation similar to the cold war affiliation.
\end{tabular}

(C) 2020 The authors. Published by SPCRD Global Publishing. This is an open access article under the Creative Commons AttributionNonCommercial 4.0

Corresponding author's email address:

\section{Introduction}

In the current international scenario, if there is any significant regional competition between two states for gaining influence in their neighbor country to achieve their national interest, it would be not wrong to say that the competition is between Pakistan and India in Afghanistan. Both India and Pakistan are looking to obtain their exclusive objectives in Afghanistan and drag sharply different tools. In between this regional rivalries Afghanistan has long been the epicenter of externally backed coups, proxy wars and violence that abruptly damage the political, economic, social fabric of the state and drag Afghanistan into poverty, miseries and backwardness. The dynamics among these three South Asian countries could be termed better in the words of Dalymple Succininctly that "three countries caught in 
deadly triangle of mutual mistrust and competition”.

Being the gateway of Central Asia, Middle East and South Asia the cockpit of Asia landlocked Afghanistan possessed significant geo-strategic importance for the regional as well as global powers. In the traditional hostility of India and Pakistan, Kabul's relations plays momentous part in the determinations of foreign as well as domestic policies of the two states. In the bilateral relations between India and Afghanistan, Pakistan is the major factor in the maintenance of cordial relations between them. Despite common faith, shared interest, close cultural and religious ties and 1200 miles long border between Pakistan and Afghanistan, they remain far friendly except on few occasions in the post 1947 era. On other hand India had always shaped its Afghan policy keeping in view Pakistan policies and strategies in Afghanistan and enjoyed more friendly relation with them contrary to Pakistan except at time of USSR intervention and then in the subsequent Taliban regime. While Islamabad reservations of Indian policy towards Afghanistan is always concerned with the persistent security threats from them as Pakistan believes that stable Afghanistan far from the Great Game of the regional and world powers is vital for Pakistan survival and existence. Pakistan always tried to seek pro-Pakistan government in Afghanistan against India to make itself safe from its eastern borders.

The current paper objective is to evaluate and analyze the role of Pakistan policies for Afghanistan that how much it affects the relations between India and Afghanistan. The investigation has analyzed the relations among the three countries in the historical perspective and has offered an indepth analysis of Indian policies towards Afghanistan in general and under BJP government in particular in the post-Taliban era after 9/11. It has tried to explore that how much Pakistan is significant in the mutual relations of India and Afghanistan. The paper has also tried to assess Afghanistan response to Indian policies after 9/11 and currently under BJP regime.

\section{Methodological framework}

The study is based on qualitative method. An analytical and descriptive method has been applied. Secondary sources like books articles, official reports, internet sources and newspaper has been used to collect data.

\section{Background}

India and Afghanistan share historical and cultural ties in the region as neighbors. Relations between the two could be traced back in the ancient Indian Mauryan Empire, which included part of today's Afghanistan. During Mughal period Afghanistan was a big threat for India for quiet long time that was superseded by Emperor Akbar. And after Mughal the British Empire too tried to make Afghanistan a buffer zone against the Russian empire as the country was strategically so crucial for the defense and survival of India. (Jin, 2017)

The agreement of 'Durand Line' between Afghan Amir Abdur Rehman Khan and the British Indian Foreign secretary Sir Henry Mortimer in 1893 demarcated the boundaries of the two states which was respected by the subsequent Afghan rulers but most of the Afghanis have seen the agreement as temporary because the line had divided tribes and families. The matter became crucial after the June 3, 1947 plan of dividing India in which Pashtun territories became part of Pakistan. The inherited Durand line became a conflict in the bilateral relations of Pakistan and Afghanistan after partition of India in 1947 and the Afghan government made claims over the Pashtun territories of Pakistan. (Rahi, 2020)

In the post-independence era Afghanistan was the sole country of casting one negative vote 
against Pakistan for the membership in the United Nations in 1947 which further disturb the bilateral relations between the two countries. (Ahmed, 2010) Afghanistan continuously put forward their territorial claim over the Pakistani's Pashtun areas of Khyber Pakhtun Khwa, tribal areas and some parts of Baluchistan up to 1970 in Sardar Daud era and even they did not participated in the Islamic conference Summit held in Lahore in 1974 over the unpleasant relations between the two states. But despite this bitterness Afghanistan did not pose any threat from its Western borders to trouble Pakistan in the 1965 and 1971 wars with India. (Hamid, 2017)

On other side Afghanistan unpleasant relation with Pakistan drew Afghan closer to India over Durand line dispute and not supporting Pakistan over Kashmir Stance. Relations between Kabul and India remained cordial in the cold war era due to Kabul bitter relations with Pakistan and close ties with India and USSR. (Sharma, 2011) Before Sub-continent Partition Jawaharlal Nehru minster of external affairs of the time in 1940 and then PM of India had rejected Afghanistan demand of re-demarcation of Durand line but after independence, the Indian changed their policy for seeking Afghanistan favor to oppose Pakistan despite some British official's statement in favor of Durand line. (Ahemd, 2010) And in the cold war era both states assume dissimilar foreign policy posture too, as India was one of those states that founded Non-Aligned Movement and Afghanistan had also followed independent foreign policy. (Pant, 2012) But bitterness between them came to the front when India being trustworthy friend of Soviet Union was the sole South Asian country that not only recognized Communist Republic of Afghanistan but supported Soviet Russian for intervention in Afghanistan in 1979. India did not condemn them but rather kept friendly relations with the Communist regime from 1979 to 1989.India continued to provide support to USSR on national and international forums and strongly backed communist group of Najibullah's Northern Alliance in the outbreak of civil war in Afghanistan. And in the outcome of that civil war, India was defeated by Pakistani sponsored Jihidi Taliban who rose to power. (Javaid, 2016)

Indian policy of supporting Soviet in Afghanistan created space for Pakistan and with United States support Pakistan became successful to set up pro-Pakistan Taliban government in Afghanistan by limiting Indian influence during afghan war. During Afghan war and subsequently in Taliban regime (1996-2001) bilateral relations between Afghanistan and India were at lowest ebb and relations between Pakistan and Afghanistan were on excellent term. During this time India extends their ties with anti-Taliban Northern Alliance, headed by Ahmed Shah Massoud that was a Tajik group. (Yousaf, 2017)

\subsection{Major turn in the relations of Indo-Pak-Afghan policy in post-9/11 era}

The $9 / 11$ attacks on USA by Taliban and the subsequent reaction of world community suddenly shattered the policies of these countries. Pakistan was forced to join US and NATO alliance as India had already announced unconditional logistic support to US. After toppling down of the Taliban regime and the creation of US supported government of Hamid Karzai provided an opportunity to India to rebuild their bilateral relations with Afghanistan. Unlike Pakistan India pursue a 'soft power' strategy of investing on civilian rather on military affairs towards Afghanistan in the initial phase of rebuilding of cordial bilateral relations between the two states. India took so many steps to satisfy their geopolitical, economic and security interest in Afghanistan. (Quresi, 2014) India offered the membership of SAARC to Afghanistan in 2005 and in 2007 the later became member of the SAARC. India continuously provided aid to Afghanistan despite some terrorist attack in Kabul over their embassy and guest houses in which so many Indians were killed rather India became the largest regional aid provider to Afghanistan up to 2011. (Javaid, 2016) 
During establishing cordial relations with India, Karzai administration and Pakistan indulge in so many issues and challenges that hindered to continued harmonious and friendly relations between them that were developed in the Taliban regime. Indo Afghan Nexus seized the opportunities to marginalized Pakistan influence in the region in order to limit their access to Central Asia. Supporting of ethnic groups from both sides further disturb the relations. Pakistan blamed Afghanistan along with Indian for assisting insurgents in the tribal areas and Baluchistan while Karzai government accused Pakistan of double game by helping Obama administration in the war against terror in Afghanistan on one side and backing insurgency resulting in terrorism in Kabul on another side. The successor of Karzai Ashraf Ghani was also in the same path of accusing Pakistan for the bad law in order situation of the country, although he showed some optimism in his early visit to Islamabad after coming into power. (Hamid, 2017)

\subsection{India Afghan Policy}

Indian policy towards Afghanistan could be divided into four phases:

- From 1947-1990 in this era due to Soviet Intervention and cold war politics India choose USSR instead of Afghanistan that adversely affected India's image in the Afghanistan.

- The second Phase is from 1991-2001 called end of cold war era, during this time India had troubled relations with Afghanistan due to Pakistani supported Taliban government and Jihidi terrorism.

- Third phase is from 2001-2014 in which India reemerged as the largest aid provider to Afghanistan in the socio-economic development and rebuilding process of Afghanistan.

- The fourth phase is India afghan relations in the BJP government and when Ashraf Ghani became President of Afghanistan after Karzai. (Singh, 2018)

After the defeat of Taliban in 2001 India immediately changed its policy towards Afghanistan. After installing full-fledged embassy in 2002 India attended the Bonn Conference actively and gave attention to the support of Afghan government and political process there. India actively participated in every international effort that aimed at political reconciliation and economic rebuilding in Afghanistan. (Pant, 2012) Bilateral relations between the two countries boost up in October 2011 when they signed a strategic partnership agreement. It was first strategic contract made by Afghanistan with India since USSR withdrawal. The Pact includes training of Afghan security personnel and socio-economic developmental projects. In 2014 three terrorist attacks on Indian consulate in Herat did not damage Indian contributions to Afghanistan reconstruction and rehabilitation. (Javaid, 2016)

Indian soft investments objectives in Afghanistan are many first, strategically Indian wanted to put their soft presence vis-à-vis Pakistan hard presence and they have keep Afghanistan in their top priorities as the latter is a valuable countermeasure to a hostile Pakistan. Some of the Indian socioeconomic, infrastructural developmental projects are as:

- The largest aid provider in humanitarian sector.

- Consume more than US \$2 billion on various socio economic projects.

- Extended support in the health capacity, communication, education and women empowerment.

- Assistance in the training of diplomats, civil servants, police and security personnel.

- India helped Afghanistan in the exploring of minerals like natural gas and oil.

- Active participation in reconstruction efforts, rebuilding of air links, roads and power plants. (Javaid, 2016)

Secondly, the Indian foreign policy makers along with the US think tank are looking forward 
that after US troop's withdrawal from Afghanistan who will be there to fill up the vacuum in Afghanistan for contributing in the stability of the country. US considered India as rising power much capable of bringing stability and playing major role in the reconstruction of Afghanistan. As US would not want to allow China to play this role and looking to India as regional power to counter China influence in order to safeguard US interest in the region. By filling this vacuum by the Indians US could easily satisfied their interest in the region. And the Indians could become a regional power against China. (Akhtar, 2015)

Thirdly, with minimizing Pakistan and Chinese influence in Afghanistan India needs Afghanistan for economic purposes as well, as the latter is located at the cross-road of Southern Asia and energyrich Central Asian countries along with Iran. India does not possess direct geographical exit to the region, so Afghanistan would be the best option for them to engage themselves with the central Asian region through land route. Fourthly, India wanted to protect the interest of Hindus and Sikhs living in Afghanistan. Fifthly and more importantly India needs Afghanistan to control Pakistan policies of manoeuvring allies with the Muslim states to achieve support for Pakistan's stand on Kashmir. (Tennyson, 2011) India believes that if they does not contain Pakistan influence in Afghanistan, it would increase the difficulties for them in the Indian held Kashmir and the Kashmir will remain a burning issue on the international front and its internationalization will benefitted Pakistan policy on Kashmir. (Yousaf, 2017)

\subsection{Indian policy in BJP Era}

As for as the foreign policies approach of BJP government towards Indian neighbors countries are concerned, they claim "Neighbors First" so following their governmental strategies Indian Prime Minister Narendara Modi wanted to project himself as innovative and decisive leader who could make things happen. PM Modi first visit to Afghanistan in December 2015 was other step of their Afghan policy in which India offered three Cheetal helicopters to counter Taliban attacks, inaugurated afghan Parliament building that was constructed with Indian support. In another visit he inaugurated the Salma Dame in Heart in 2016. In order to minimized Pakistan influence over Afghan affairs India and Afghanistan decided to improve connectivity through Iran's Chabahar Port instead of Wagha-Attari border. So in $2017 \mathrm{Kabul}$ and New Delhi launched an air freight corridor through Iran Chabahar port and the shipment of wheat to Afghanistan was the first Indian shipment through this transit that was dispatched from India's Kandla port (Kaura, 2020)

\subsection{Current Indian Policy of BJP after US Taliban agreement in Doha}

The agreement signed between US and Taliban in Doha on February 29, 2020 is hardly desirable for India as the treaty concludes that US troops are expected to withdraw from Afghanistan by the end of 2021, and if it successfully implemented Taliban might be able to play larger role in Afghan politics. The Indian assets in Afghanistan safety would be endangered and in future their investment would not able, as Haqqani group is a faction of Taliban that is a big challenge to Indian investment after US troop's withdrawal. (Chuadhuri, 2020) Besides these Indian perceptions they remained sidelined from these peace talks because it was brokered by Pakistan. India wanted to continue with a low key developmental approach to crises resolution in Afghanistan and is reluctant to participate in the stabilization of Afghanistan by scaling up military cooperation. (Kaura, 2020)

New Delhi had troubled over the signed deal of Taliban and US over Afghanistan and did not take active role as the pact was one sided for them. Although Afghanistan called the Indian to open political negotiations with Taliban directly over terrorism being main stakeholder in the region and in the stabilization of Afghanistan but India views it in their own prism as they wanted no deal or a deal 
which did not favored Pakistan. The adaptation of this policy by BJP government has some reasons, firstly being the largest regional aid provider to Afghanistan they do not want to gamble its partnership with afghan government in establishing political dialogue with Taliban. Secondly Indians considered all the terrorism related concern predominantly Pakistan-centric rather Taliban. Thirdly BJP believes that Taliban still possessed anti-Indian and pro-Pakistan sentiments. Fourthly it is unclear to them that what will be the procedure and who will lead the dialogue along with India either US or any other actor if New Delhi decided to open dialogue with Taliban. In the future policy of India towards Afghanistan they can no longer remain a mere spectator in Afghan peace and pursues more clearer role from Pakistan and seeking itself to play observer's role in future peace negotiations among the main stakeholders of Afghanistan. (Ahmad, 2020)

\subsection{Afghanistan Response}

Afghanistan has witnessing continuous wars and the rise and fall of various ideologies for more than thirty nine years. The military interventions of USSR, Pakistani backed Taliban and US \& NATO forces while the ideologies are Communism, radical Islam, and liberal democracy. Unfortunately Afghanistan came to be understood more as buffer state where external powers play great games and in the outcome they suffered a lot. Indian policies towards Afghans are unreliable being a regional partner during and after Cold war but Afghanistan have always responded positively to their policies. (Paliwal, 2017)

The emergence of Karzai regime after Taliban in Afghanistan responded enthusiastically to Indian policies as Karzai had obtained much of his education in India and he wanted to pursue cordial relations with India. In his governmental tenure he visited India for fourteen times including three visits in one year to demonstrate on Indians that he is not an ordinary friend of India. (Chand, 2013)

Karzai administration had pursue the traditional strategy of pursuing national objectives by relying on powerful nations so as compared to Pakistan it was clear for him to gain more from consolidating ties with Delhi than from doing so with Islamabad despite the fact that the latter is a valuable trader by location. During Karzai term from 2001-2014 the relations between Pakistan and Afghanistan was more chaos than reliable, and was very much pro-Indian because of the affected strategies which they have employed in the cold war. As compared to other neighbours Pak-Afghan relations were more unsound, suspicious and dubious. During Ghani era some sober development like sharing of intelligence were occurred by which the arrest of some nominal terrorists come to the front and bilateral relation took some turn which had calmed the Indian policy makers and they were taking some time to warm up but they sent their displeasure through diplomatic signals and Afghanistan changed their policy once again by accusing Pakistan that they had provide safe heavens to the terrorists near Pak Afghan borders. (Khalil, 2016)

The Afghan public opinion along with their policy makers considered Pakistan as responsible for presence of Taliban and terrorism. They believe that unlike India Pakistan is continuously interfering in Afghanistan internal matters. As compared to India Pakistan recognition on donor countries are very low in the educational and socio-economic sectors of Afghanistan. Afghan anger for Pakistanis and love for Indian content is the routine feature on social media in Afghanistan. Even the refugees living in Pakistan since USSR interventions have also reservations and they are continuously complaining about the attitude they faced in social and educational forums that resulted love for Indians and hater for Pakistan, as Indian media intentionally pointing out and propagating all the anti-Pakistan content through which they could accused Pakistan for all the unfortunate of Afghanis and not acknowledging Pakistan's tremendous support and hospitality which they did with Afghanistan. (Balouch, 2014) 
"India is viewed favorably by many Afghans as the enemy of their enemy" because Afghans believe that Pakistani establishment is the key supporter of the Taliban insurgency in their country and wanted to create hurdles in the new air and sea routes between India and Kabul in order to continue Kabul dependency on Pakistan .Afghans are suspicions that Pakistan is looking to extend its leverage and seeing India as the power that can pressure Pakistan enough to escape them after US withdrawal as "For Kabul, India is vital counterbalance to an aggressive neighbor". (Kumar, 2019) That is why during BJP and Ghani administration they both are busy to criticize Pakistan harshly and publically. BJP antiPakistan agenda always support them in the election process for coming into power while Ghani usually said that "the biggest challenge for Afghanistan is not the Taliban or Al-Qaeda but the state to state relations with Pakistan". Ghani believes and has clearly told that Pakistan verbal assurance would not open the door of improvements of ties between Pakistan and Afghanistan, Pakistan positive actions could improve the bilateral relations and these developmental ties would not come at the cost of Afghanistan relations with India at this time. (Khalil, 2016)

\subsection{Pakistan Factor}

“As Pakistan increasingly became our problem, Afghanistan emerged as kind of counter. To keep Pakistan on its toes, friendly relations with Afghanistan, which always created a kind of anxiety in Pakistan, were kept up.(Laith Mansingh,foreign secretary of India 1999-2001)” (Paliwal, 2017)

Indian policy makers have always designed their Afghan policy keeping in view Pakistan factor. New Delhi always favored a scenario in Afghanistan that is anti-Pakistan, that is why in the 2020 peace dialogue in Doha between US and Taliban New Delhi has viewed it in the prism of anti-Pakistan strategy. New Delhi predominantly considered terrorism as Pakistan -centric and not directly related to Taliban. (Ahmad, 2020)

"Afghanistan has been a prize that Pakistan and India have fought over directly and indirectly for decades" (Robert Kaplan). Objectives of Pakistan policies of supporting Anti-Soviet elements and then Taliban government and approaching to the various war in and around Afghanistan by Pakistan was none but its national security and interest and that is "balancing India" and now India's growing influence in Kabul is a threat to Pakistan security. Pakistan sees Iran's Chabahar port with Indian assistance as rival to Gwadar port built with China help as to reduce Pakistan strategic influence for Afghanistan and Central Asia. (Bajoria, 2009) Pakistan concern over Indo-Afghan nexus is that she feared that India role in Afghanistan is not confined to developmental efforts only rather wanted to create instability in Pakistan particularly in Baluchistan, FATA and Khyber PakhtunKhwa by ensuring its presence in Afghanistan. (Sial, 2011)

Pakistan with its Afghan policy had appeared that without declaring itself a regional superpower with its propped economy, she shares the same table with China and US in any peace dialogue about Afghanistan while India always operated with its hands tied whenever there are any negotiations regarding Afghanistan future. And India would never allow Pakistan diplomatically to play this crucial role in shaping its strategy in Afghanistan. India believes that Pakistan strategy of hedging its interest in Afghanistan would become easier as compared to other regional partners after US and NATO troops withdrawal so Pakistan would oppose any move that delayed US presence in Afghanistan. And with the reduction of US influence in Afghanistan Indo-Afghan economic and other relationships would be at severe risks. In addition to manage its affairs with US Pakistan is busy to utilize China by developing trade and various transit routes to counter India and US in the region and also trying to deal with its incongruity with Iran over strategic approach to Afghanistan and Central Asia by developing Pak-Iran gas pipe line project. (Gulati, 2013) 
Pakistan suspension of trade ties with India after the Indian decision of scraping special status of Kashmir in 2019 further affected the policy of these regional competitors as Pakistan forbids Afghanistan from overland trade with India as Chabahar port is still underdeveloped and Pakistan denial of the land routes to both countries would affect the trade and economic relations for a while. India considered Iranian Chabahar port much crucial to circumvent Pakistan while Afghanistan wanted to reduce their economic dependency on Pakistan by developing strong relations with India. (Constantino, 2020)

\section{Conclusion}

Like every sovereign state Afghanistan also seeks to have full autonomy in pursuing their national interest by keeping warm relations with neighbors and other regional as well as global states. Being an emerging newly industrialized state having good international image and demonstrating transparent presence in the economic activities of Afghanistan India wanted to acquire an advantageous sway from Pakistan in Afghanistan. India does not want to deploy its military in Afghanistan and wanted to implement trade and economic policies in Afghanistan for pursuing its interest as she measured that to counter Pakistan influence in Afghanistan trade is the weapon for them in which they are stronger than the sheer economy of Pakistan. India wanted a driving seat in the reconstruction of Afghanistan after the withdraw of international forces but she is aware that Pakistan being facilitators of Taliban in the Past still possessed much influence in them would never allow them to play this role. The Indian silence over Doha Pact is the evidence of this fact as they wanted to have a share in any negotiations about the future of Afghanistan but Pakistan policy makers became successful to keep them aloof from the dialogue.

The Afghanistan response to the Indians objectives is much positive as they viewed Indian growing profile suitable to the development of their country. They always accused Pakistan Intelligence agencies for backing terrorism in their state and considered that the war in their country is nothing but a part of Pakistan's struggle with New Delhi. Afghanistan strongly supported India policy of constructing all the trade routes that bypass Pakistan in order to create hurdles for their crippling economy. Moreover the policy would also serve the Afghanistan objective of reducing dependency on Pakistan. The serious concern for Afghan policy makers is how to protect their land from becoming battlefield for further proxy wars between other powers and at the moment BJP government policies are looking sober to them to help them in reducing this fear.

This current close state of affairs between these two countries could not be termed permanently as the main factor behind this engagement is mainly due to Pakistan opposition of both countries and if the status quo in South Asia changed due to any regional or international happening, estrangement could be witnessed in them. Afghanistan should understand that due to the past three, four decades war they has to live with its domestic and regional realties and to think more in regional terms. Peace, stability in the region is in the best interest of all these three states. Along with Afghanistan Pakistan also faces extensive security threats from militant groups that were the outcome of Indian-Afghan alliance. The resolving of Kashmir dispute with India is in the wish list of Pakistan since its independence as the latter seeks undo the territorial status quo in the Kashmir region which is overrule by the Indians always since independence. The issue of Kashmir if phenomenally resolved, would it change the policy options of both countries in Afghanistan having contrast ideological calculus and different objectives?

The answer would be uncertain and mainly concerned would 'wait and see strategy'. Besides Kashmir the other major risks for the policy makers of India and Pakistan are about the little clarity of 
Taliban who are operating from Afghan soil and are involved in the bombing and killings of Indian and Pakistani personnel in Afghanistan after 9/11. The trust deficit between Indian and Pakistan intelligence agencies and the increasing political instability in Afghanistan are the other risks to the interest of both states regarding Afghanistan.

\section{References}

Ahemd, N. (2010). Pakistan's Afghan Policy: Historical Perspective 1947-1977. Pakistan Journal Of History And Culture, vol xxxI,no 2.

Ahmad, J. (2020, May 12). Will India Amend Its Approach To Afghaistan Peace? Retrieved June 14, 2020, from www.atlanticcouncil.org: https://www.atlanticcouncil.org/blogs/new-atlanticist/willindia-amend-its-approach-to-afghanistan-peace/

Ahmed, S. (2010). Pakistan In World Affairs. Lahore: Jahangir Books.

Akhtar, R. a. (2015, Janyary). Pakistan, India And China After The US Drawdown From Afghanistan A Visiting Fellow Report. Retrieved June 12, 2020, from https://www.stimson.org/wpcontent/files/file-attachments/pakistan-india-china-after-us-afghanistan.pdf

Bajoria, J. (2009, July 22). India-Afghan Relations. Retrieved June 15, 2020, from www.cfr.org: https://www.google.com/search?q=india+afghan+relations+by+bajoria\&oq=india+afghan+rela tions+by+bajoria\&aqs $=$ chrome..69i57.19081joj7\&sourceid $=$ chrome\&ie $=U T F-8$

Balouch, H. (2014, January 8). Afghanistan And Pakistan: Friends Turned Foes? Retrieved June 15, 2020, from www.dawn.com: https://www.dawn.com/news/1083088

Chand, M. (2013, December 13). Hamid Karzai's 14th Visit To Delhi: A New Role's For India. Retrieved June 14, 2020, from mea.gov.in: http://www.indiawrites.org/diplomacy/hamid-karzais-14thvisit-to-delhi-a-new-role-for-india/

Chuadhuri, R. ,. (2020, June 2). Dealing With The Taliban: India's Strategy In afghanistan After US withdrawl. Retrieved june 12, 2020, from carnegieindia.org: https://carnegieindia.org/2020/o6/o2/dealing-with-taliban-india-s-strategy-in-afghanistanafter-u.s.-withdrawal-pub-81951

Constantino, Z. (2020). The India Pakistan Rivalry In Afghanistan. Special Report 362, United States For Peace, Washington DC.

Gulati, M. (2013, May 28). The Pakistan Factore In India's Afghan Policy. Retrieved June 17, 2020, from www.vifindia.org: https://www.vifindia.org/article/2013/may/28/the-pakistan-factor-in-indias-afghanistan-policy

Hamid, M.-U. (2017, January). Pak-Afghan ties: Evoultion, Challenges And The Way Forward. Researchgate .

Javaid, A. (2016, January). Indian Influence In Afghanistan And Its Implication For Pakisan. Researchgate .

Jin, W. (2017). India's Policy Towards Afghanistan: Implications To The Regional Security Governance. Asian Journal Of Middle Eastern And Islamic Studies , 11,No.4.

Kaura, V. a. (2020). India's Neighbourhood Policy During 2014-2019: Political Context And Policy Outcomes. Indian Journal Of Public Adminstration , 66(1).

Khalil, B. A. (2016, December 16). Partition, The Tangled History Of The Afghanistan-India-Pakistan Triangle Kabul Foreign Policy Approach Has Shifted Between Favouring India And Pakistan Since The. Retrieved June 15, 2020, from thediplomat.com: https://thediplomat.com/2016/12/the-tangled-history-of-the-afghanistan-india-pakistantriangle/

Kumar, R. a. (2019, February 28). Afghans Are Cheering For An Indian Win. Retrieved June 15, 2020, from foreignpolicy.com: https://www.google.com/search?q=afghans+are+cheering+for+an+indian+win\&oq=afghans+a 
re + cheering + for + an + indian + win\&aqs $=$ chrome..69i57j6gi6o.26649joj4\&sourceid $=$ chrome\&ie $=$ UTF-8

Paliwal, A. (2017). My Enemy's Enemy India In Afghanistan From The Soviet Invasion To The US Withdrawl. New York: Oxford University Press.

Pant, H. V. (2012). India's Changing Afghanistan Policy: regional And Global Implicatin. Army War college Strategic studies institute 47,Ashburn driveCarlisle, Strategic Studies Institute. SSI.

Quresi, A. (2014, September 3). How India Is Using 'Soft Power'To Secure Energy Interest. Foreign Policy Journal .

Rahi, A. (2020, June 11). Would India And Afghanistan have had a close relationship had not been founded? Retrieved June 12, 2020, from https://www.dawn.com/news/1353172

Sharma, R. (2011). India Relations With Afghanistan. UK: David Scott, Routledge.

Sial, S. (2011). Pak-Afghan Relations Emerging Trends And Future Prospect. Pak Institute For Peace Studies , 4 no 1.

Singh, P. (2018, November 22). Indo-Afghan Relations: Turning A New Page Under Modi? Retrieved June 2020, 15, from https://charches.wordpress.com: https://charchacas.wordpress.com/2018/11/22/indo-afghan-relations-turning-a-new-pageunder-modi/

Tennyson, K. N. (2011, July). Issue Brief- Reassessing India's Role In Afghanistan. Researchgate Publications .

Yousaf, N. a. (2017). Pakistan-Centric Foreign Policy Of India. Journal Of The Resarch Society Of Pakistan , 54 No (1). 